ORIGINAL ARTICLE

\title{
A new termite species of the genus Dihoplotermes Araújo (Blattaria, Isoptera, Termitidae) from the Brazilian Amazonian rainforest
}

\author{
Renato Almeida de AZEVEDO ${ }^{1, *}$, Cristian de Sales DAMBROS ${ }^{2}$, José Wellington de MORAIS ${ }^{1}$ \\ Instituto Nacional de Pesquisas da Amazônia - INPA, Coordenação de Biodiversidade - COBIO, Av. André Araújo, 2936, Petrópolis, 69083-000, Manaus, AM, Brazil \\ 2 Universidade Federal de Santa Maria, Departamento de Ecologia e Evolução, Av. Roraima, 1000-7, Camobi, 97105-900, Santa Maria, RS, Brazil \\ * Corresponding author: azevedo.inpa@gmail.com
}

\begin{abstract}
Dihoplotermes, a previously monotypic genus, is now composed of two species. Dihoplotermes taurus sp. nov., a new Termitinae termite species, is illustrated and described based on morphological characters from soldiers, workers, and imago. The new species is distinguished from Dihoplotermes inusitatus Araujo by having a spine-like protuberance with blunt apex on the postmentum, the presence of a spine on the gizzard and the absence of dimorphic soldiers. Furthermore, the internal morphological characteristics of a Dihoplotermes worker are described for the first time. Both internal and external morphological characters were used to improve the characterization of the species.
\end{abstract}

KEYWORDS: gizzard, soil fauna, taxonomy, termite, Termitinae

\section{Uma nova espécie de térmita do gênero Dihoplotermes Araujo (Blattaria, Isoptera, Termitidae) da floresta Amazônica Brasileira}

\section{RESUMO}

Dihoplotermes, que era um gênero monotípico, agora é composto por duas espécies. Dihoplotermes taurus sp. nov., uma nova espécie de cupim Termitinae, é descrita e ilustrada com base nos caracteres morfológicos dos soldados, operários e imago. A nova espécie se diferencia de Dihoplotermes inusitatus Araujo por apresentar uma protuberância em forma de espinho não pontiagudo no posmento, presença de um espinho na moela e ausência de soldados dimórficos. Além disso, são descritas pela primeira vez as características morfológicas internas de um operário de Dihoplotermes e utilizamos ambos caracteres morfológicos internos e externos para melhor caracterizar as espécies.

PALAVRAS-CHAVE: fauna de solo, moela, taxonomia, cupim, Termitinae

\section{INTRODUCTION}

Termitinae is a polyphyletic subfamily (Inward et al. 2007; Bourguignon et al. 2015; Bourguignon et al. 2017) belonging to the Termitidae, which is a morphologically diverse group, composed by 661 species described worldwide (Constantino 2018). In the Neotropical Region, five Termitinae genera have soldiers with asymmetrical mandibles. Three genera have the cephalic capsule with a frontal projection (Cornicapritermes Emerson, Dihoplotermes Araujo, Palmitermes Hellemans \& Roisin), whilst other two genera do not exhibit this feature (Neocapritermes Holmgren and Planicapritermes Emerson). The presence (in Dihoplotermes) or absence (in Cornicapritermes and Palmitermes) of two anterolateral spines near the base of the mandible distinguishes the first three genera. In Neocapritermes, the spine is located dorsally and only found on the left mandible (Krishna and Araujo 1968). Dihoplotermes is more closely related to Spinitermes Wasmann and Cavitermes Emerson than to other Termitinae genera. This genus shares with Spinitermes a conspicuous frontal projection on the top of the head (Inward et al. 2007; Bourguignon et al. 2017; Hellemans et al. 2017).

Dihoplotermes was described by Araújo (1961) and revised by Krishna (1968) and Mathews (1977). Until now, Dihoplotermes inusitatus Araujo, 1961 was the only species described. The main characteristics of the soldiers belonging to this genus are the presence of spines on the lateral sides of the head near the mandible base, the long, anteriorly pointed conical frontal protuberance on the head, and the asymmetrical mandibles, the left one being slightly sinuous (Araújo 1961; Constantino 2002). Furthermore, D. inusitatus 
has dimorphic soldiers. The large (major) soldiers have the head protuberance pointed upwards, covering part of the mandibles and evident in lateral view, whereas the small (minor) soldiers have the protuberance only pointed upwards.

Here we describe a new Dihoplotermes species from the Amazon Region. All three castes (soldier, worker and imago after wing loss) are illustrated. Dihoplotermes taurus sp.nov. does not have dimorphic soldiers, lacks the protuberance on the postmentum and has a spine on the gizzard. We used both internal and external morphological characters to improve the characterization of the species.

\section{MATERIAL AND METHODS}

External characters of the soldier and imago castes and the external and internal characters of the worker caste were described. Terminology for the worker mandible follows Fontes (1987). The digestive tube terminology follows Noirot (1995; 2001). Internal characters of the imago were not analyzed, because there was only one specimen in our samples.

Morphometric characters follow the Roonwal's system (Roonwal 1970), when applicable, and are indicated in parenthesis: LH, head capsule length until the tip of the projection in soldiers and until the end of the labrum in workers and imagoes; LHM, head length in lateral view until the base of the mandibles (5); LM, mandible length (37); $\mathrm{WH}$, maximum head width, including the eyes in the imago (17); LT, length of hind tibia (85); $\mathrm{HH}$, head height excluding postmentum (21); WP, mean pronotum width (68); $\mathrm{DE}$, maximum eye diameter, excluding ocular sclerite (49); LP, mean pronotum length.

Images were taken with a Leica DFC500 digital camera connected to a Leica MZ205 stereomicroscope linked to a computer with the Leica Application Suite software, which includes an Auto-Montage module. Drawings were made with Inkscape software and measurements were taken with a ocular micrometer. The distribution map of the species was made using SimpleMappr according to Shorthouse (2010).

\section{RESULTS}

\section{Genus diagnosis}

The soldiers of Dihoplotermes taurus and Dihoplotermes inusitatus have two anterolateral spines near the base of the mandibles, above the mandibular condyle; asymmetric snapping mandibles (Figure 1); asymmetrical labrum; and tibial spurs 3:2:2. Workers of both species have similar mandibles, with apical teeth distinctly larger than the first marginal teeth; right mandible without second marginal tooth; left mandible with third marginal tooth absent and molar tooth separated from first + second marginal by a small incision (Figure $2 \mathrm{D}$ ). The gut of both species has similarities regarding the gizzard, with a spine on the pulvillus (Figure

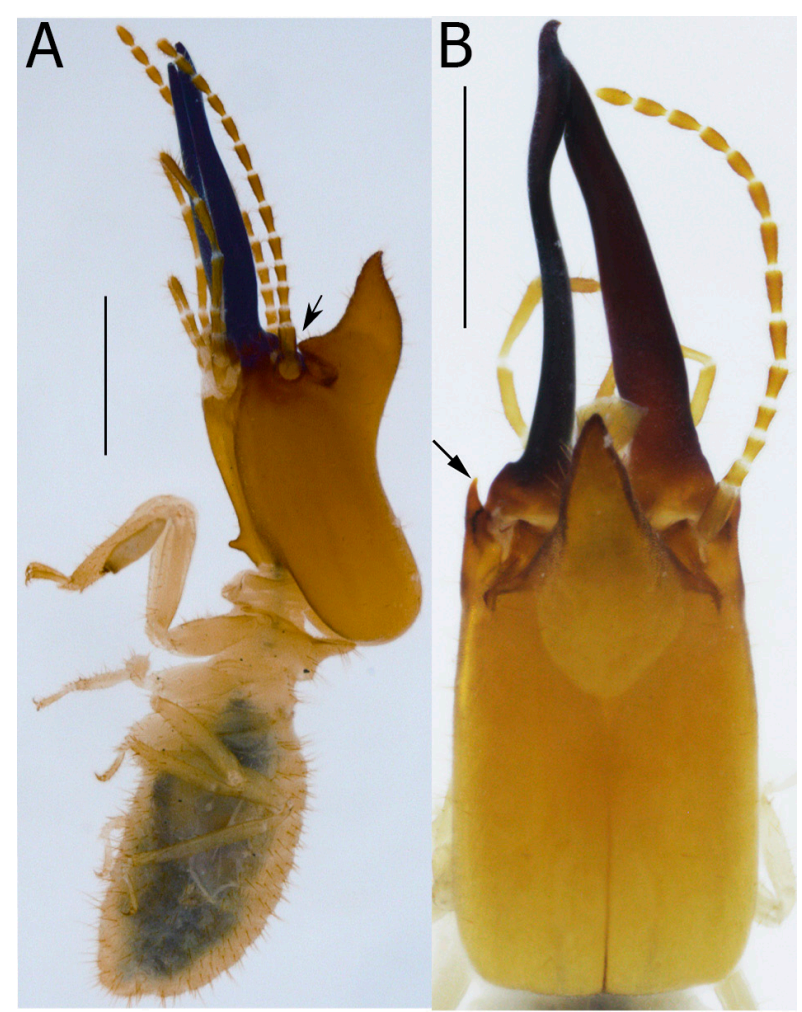

Figure 1. Soldier of Dihoplotermes taurus, sp. nov. (A). Head in lateral view (arrow points to the small step above the mandibles); (B). Head in dorsal view (arrow points to the spine in the anterolateral portion of the head capsule). This figure is in color in the electronic version. Scale bar $=1 \mathrm{~mm}$

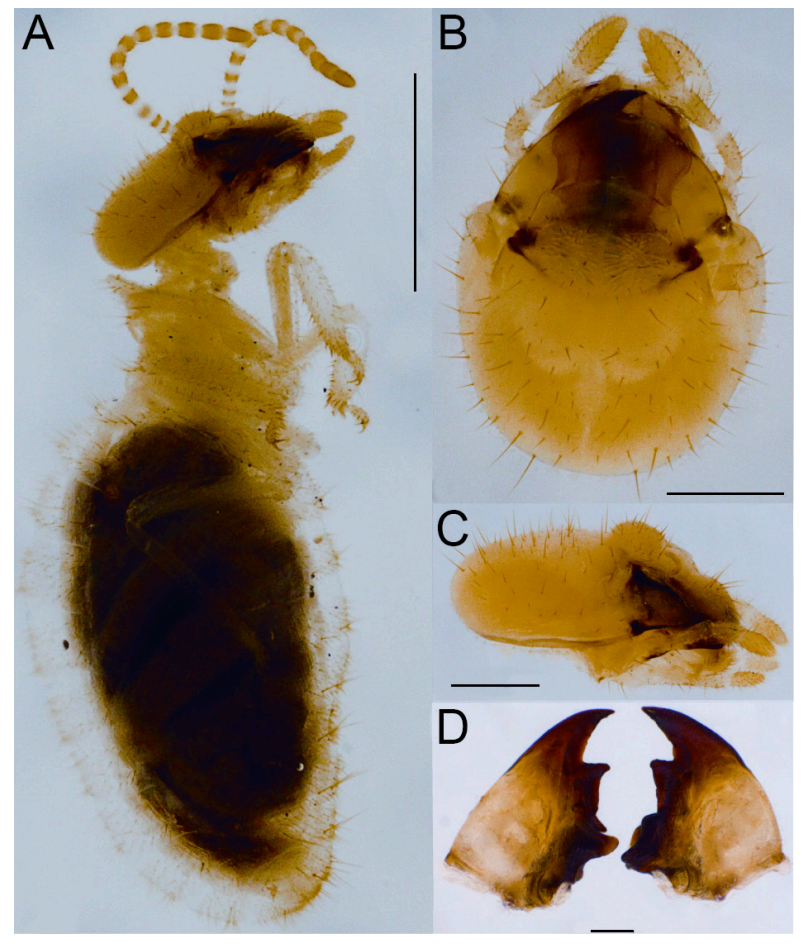

Figure 2. Worker of Dihoplotermes taurus, sp. nov. (A). Lateral view; (B). Head in dorsal view; (C). Head in lateral view; (D). Mandibles. This figure is in color in the electronic version. Scale bars: $A=1 \mathrm{~mm} ; B=0.3 \mathrm{~mm} ; C=0.3 \mathrm{~mm} ; \mathrm{D}=0.1 \mathrm{~mm}$. 
7 B-C); presence of a malpighian nodule with two pairs of malpighian tubules inserted on the nodule (Figure $1 \mathrm{~A}$ ); enteric valve with a longitudinal row of spines on one cushion (Figure 7 D-E).

Dihoplotermes taurus Azevedo, Dambros \& Morais sp. nov.

Etymology. From the Latin "taurus", which means "bull", referring to the shape of the soldier's head capsule and the behavior of the soldiers during collection, when they inclined their heads resembling a bull's attack.

The species is registered in ZooBank at <http://zoobank. org/NomenclaturalActs/F9E1 FF88-4034-45B9-A369A5A7056EF1B2>

\section{Material examined}

Holotype. Soldier, in alcohol $80 \%$, separated in microvial. Original label: "Brazil, Amazonas, Manaus, F. E. UFAM, L3 5500 (80-85), 2³8’00”S, 6006’26”W. Coleta Manual 20/31vii-2012. Azevedo. R. A. coll”. The holotype was deposited in the Invertebrate Collection of the Instituto Nacional de Pesquisas da Amazônia - INPA (INPA-ISO 000001).

Paratypes. Four soldiers and 15 workers with the same data as the holotype (INPA-ISO 000002); two soldiers, six workers and one imago with the following data: "Brazil, Amazonas, Manaus, F. E. UFAM, L4 5500 (180-185), 2³7’31”S, 6006'22”W. Coleta Manual 20/31-vii-2012. Azevedo. R.A. coll" (INPA-ISO 000003); three soldiers and one worker with the following data: "Brazil, Amazonas, Manaus, F. E. UFAM, L3 5500 (130-135), 2³8’00”S, 6006'26”W. Coleta Manual 20/31-vii-2012. Azevedo. R. A. coll” (INPA-ISO 000004), and five soldiers and nine workers with the following data: "Brazil, Amazonas, Manaus, F. E. UFAM, L4 5500 (130-135), 2³7’31”S, 6006'22”W. Coleta Manual 20/31-vii-2012. Azevedo. R. A. coll” (INPA-ISO 000005). The specimens were deposited in the Invertebrate Collection of the Instituto Nacional de Pesquisas da Amazônia (INPA).

\section{Description}

Soldier (Figure 1 A-B). Head capsule yellowish, rectangular, with few bristles of distinct length distributed irregularly for almost the entire head extension. Head protuberance apex with a high density of bristles. One spine in each anterolateral part of the head capsule, near the base of the mandibles (Figure 1 A). Prominent projection on frontal side of the head capsule, covering part of the labrum and almost reaching the lateral margins in dorsal view. Concavity on the antero-inferior portion of the head projection, above the mandibles, forming a small step in lateral view, with two small projections on its margins, just above the antennal insertions. Postmentum narrower in the middle portion. Anterior portion of the postmentum slightly wider than the posterior portion, with a spine-like projection at the posterior edge of postmentum, visible in lateral view. Mandibles asymmetrical and dark (Figure 1. B). Left mandible, in the first two-thirds of its proximal portion slightly curved towards the internal margin; distal portion slightly wider, but narrowing toward the apex, and curving to the right in a sickle shape, forming a small incision in which the right mandible fits. Right mandible approximately straight on the external margin, narrowing towards the apex, also with an incision in which the left mandible fits when closed. Apex pointed, slightly curved to the left. Symmetrical labrum, with seven to eight long bristles distributed usually in two rows. Apex slightly curved, with pointed anterior margins. Antennae with 14 articles. Antennomer I approximately three times longer than II < III $=$ IV $<$ V $<$ VI $=$ VII and VIII. The other antennomeres are equally sized. Pronotum, mesonotum, and metanotum with long and spaced bristles, distributed on the margins; pronotal anterior part with microscopic hairs. Abdomen with tergites and sternites covered by long bristles. Foretibia with few long setae irregularly distributed throughout its surface. Tibial spurs 3:2:2; with presence of a spine on the mesotibial distal region, close to the spurs, that could be mistaken for a third spur. Tibial spine is found in all castes. Measurements of soldiers are presented in Table 1.

Worker (Figure 2 A-D). Head capsule whitish, with bristles of different sizes, evenly spaced, except for the anterior margin. Fontanelle slightly conspicuous (Figure 2 B). Postclypeus slightly inflated, with few bristles. Labrum with density of bristles similar to the clypeus (Figure $2 \mathrm{C}$ ). Antennae with 14 articles. Antennomere I > II, and the following gradually increasing in length. Left mandible with apical tooth bigger and a little longer than first + second marginal; internal margin of the apical tooth slightly concave, with a small incision between first + second marginal and molar tooth. Molar prominence conspicuous, without ridges. Right mandible with apical tooth well developed, longer than the first marginal. Second marginal not noticeable. Molar plate slightly concave,

Table 1. Measurement of soldiers, workers and imago of Dihoplotermes taurus sp. nov (mm).

\begin{tabular}{|c|c|c|c|c|c|}
\hline \multirow[t]{2}{*}{ Measurement } & \multicolumn{2}{|c|}{ Soldier } & \multicolumn{2}{|c|}{ Worker } & \multirow[t]{2}{*}{ Imago } \\
\hline & range & mean & range & mean & \\
\hline Head width & $1.07-1.28$ & 1.20 & $0.77-0.85$ & 0.82 & 1.09 \\
\hline $\begin{array}{l}\text { Head length with } \\
\text { projection }\end{array}$ & $2.07-2.51$ & 2.32 & - & - & - \\
\hline Head length & $1.53-2.00$ & 1.86 & $0.98-1.10$ & 1.05 & 1.16 \\
\hline Head height & $0.76-0.89$ & 0.84 & $0.38-0.44$ & 0.39 & 0.51 \\
\hline Hind tibia length & $0.94-1.07$ & 1.02 & $0.80-0.85$ & 0.82 & 1.25 \\
\hline Pronotum width & $0.56-0.66$ & 0.63 & $0.41-0.48$ & 0.44 & 0.90 \\
\hline Pronotum length & - & - & - & - & 0.52 \\
\hline Mandible length & $1.71-2.05$ & 1.93 & - & - & - \\
\hline Eye diameter & - & - & - & - & 0.26 \\
\hline $\begin{array}{l}\text { Number of } \\
\text { specimens }\end{array}$ & 18 & & 17 & & 1 \\
\hline
\end{tabular}


without ridges (Figure 2 D). Microscopic hairs on the pronotal anterior portion, long bristles on the anterior margin of pro-, meso- and metanotum. Abdomen transparent, tergites and sternites densely covered by short bristles and by a row of long bristles on the posterior portion of each sternite (Figure $2 \mathrm{~A}$ ). Foretibiae slightly widened with many bristles of distinct sizes distributed throughout its surface.

Digestive tube (Figures 3 - 4). Soldiers and workers have similar digestive tube configuration. Gut forming a dense mass, slightly longer than wide. Proximal portion spiralshaped, posterior to the crop in dorsal view (Figure $3 \mathrm{~A}$ ). Crop enlarged, tapering towards the gizzard in which it connects. Gizzard small, columnar belt with six folds of the first and

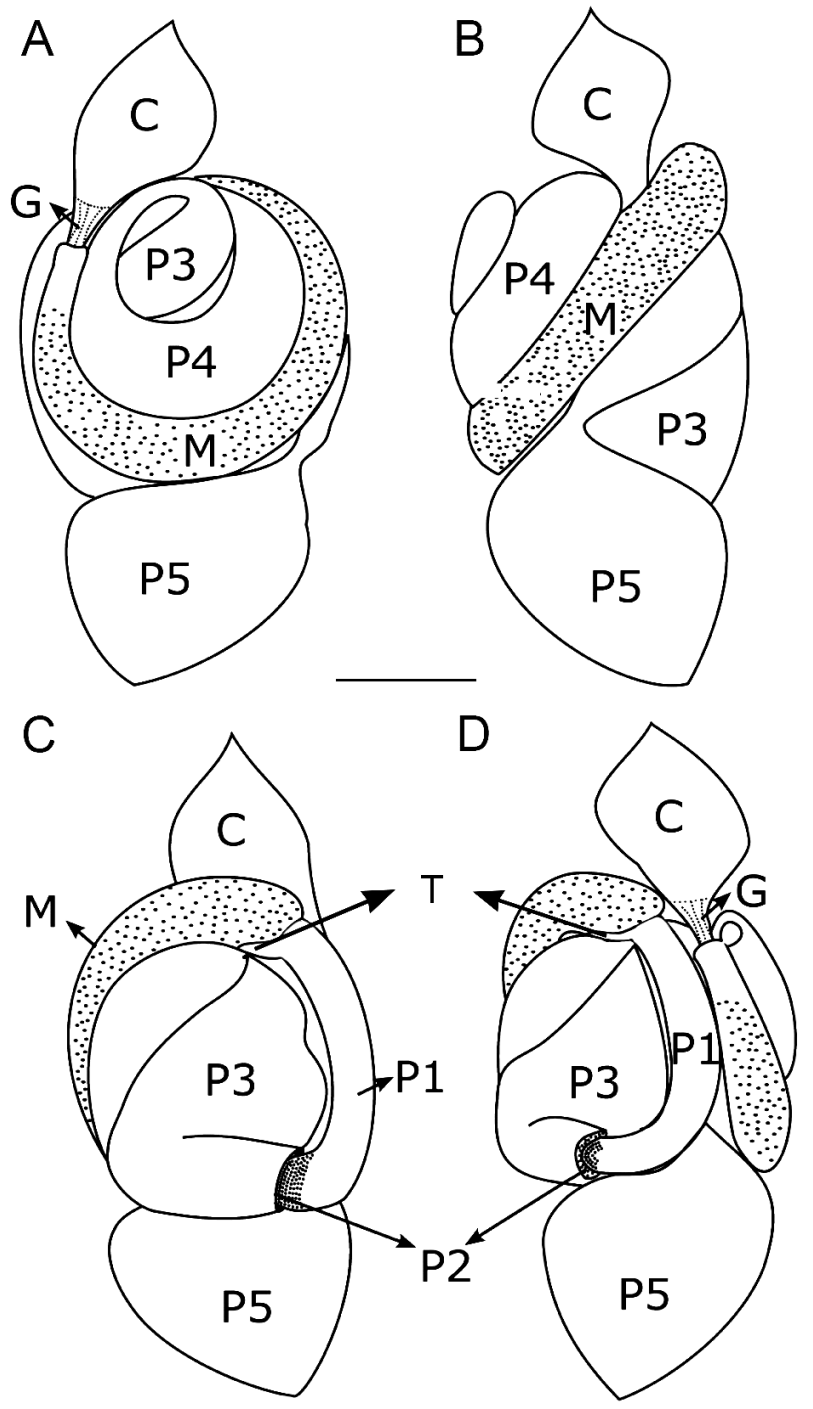

Figure 3. Digestive tube of the worker of Dihoplotermes taurus, sp. nov. (A) Ventral view; (B) Right view; (C) Ventral view; (D) Left view. C, crop; G, gizzard; M, mesenteron; $\mathrm{P} 1$, first proctodeal segment; $\mathrm{P} 2$, enteric valve; $\mathrm{P} 3$, paunch; $\mathrm{P} 4$, colon; $P 5$, rectum; T, mesenteric tongue (enlarged for better viewing). Scale bar $=0.5 \mathrm{~mm}$. second order (Figure $4 \mathrm{~B}$ ); first order pulvillus with a short spine in the medial region (Figure $4 \mathrm{C}$ ); columnar belt absent; gizzard connects to the anterolateral region of the mesenteron, which is slightly widened (Figure $3 \mathrm{D}$ ). Malpighian nodule visible on the mesenteric tongue; mesenteric tongue short and only visible when dissected and under the microscope; two pairs of malpighian tubules inserted at the same point of the nodule (Figure $4 \mathrm{~A}$ ). In ventral view: connection of mesenteron with the ileum occurs at the same height of the connection of the crop with the gizzard (Figure $3 \mathrm{C}$ ). Ileum tubular, slender and short. Ileum starts at the left side of the anterior region and ends in the posterior left side of the posterior region, where it connects with the paunch. Enteric valve with six cushions of diverse shape and size (Figure 4 D); five cushions with few short spines distally; one cushion with a row of longitudinal spines distally (Figure $4 \mathrm{E}$ ). Paunch subdivided into two parts in ventral view; one part is smaller and tubular shaped and connected with the ileum. The second part is larger and wider, tapering towards the apex, partially covered by the colon in dorsal view. Paunch with a small, narrowing and slightly curved in the area near the colon. Colon widened, always wider than the mesenteron. In dorsal

\section{A}
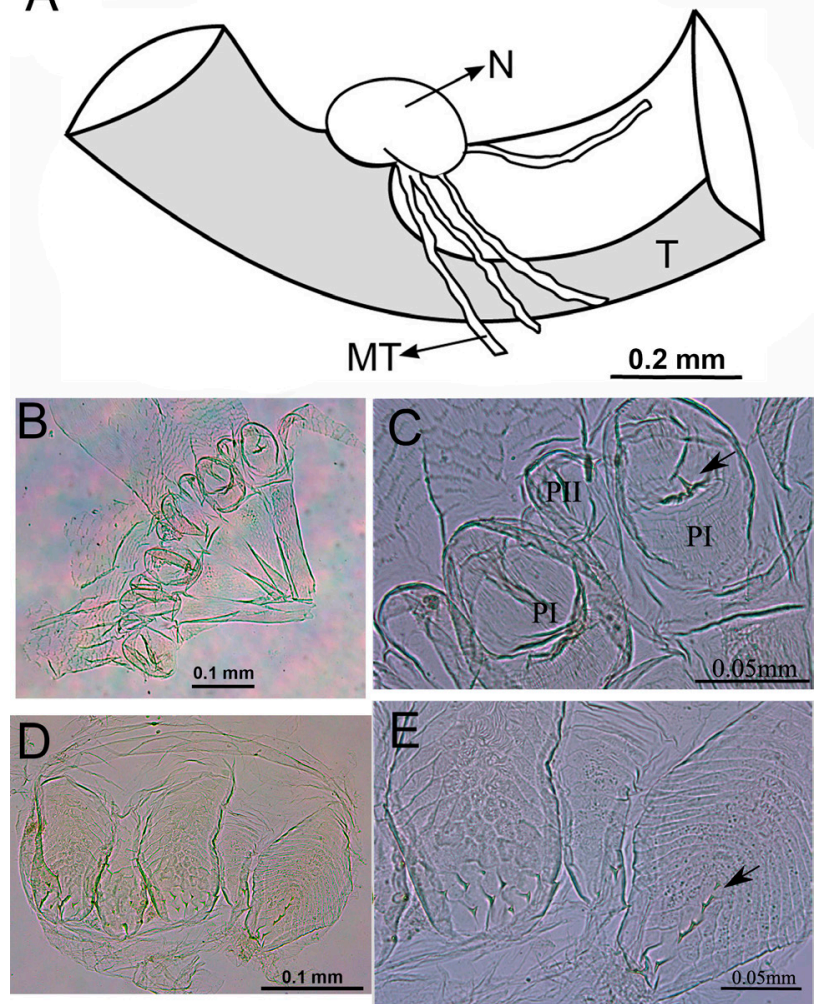

Figure 4. Digestive tube of the worker of Dihoplotermes taurus, sp. nov. (A) Insertion of Malpighi tubules; (B) Gizzard; (C) PI, pulvilli l; PII, pulvilli II (arrow points to a spine on the gizzard); (D) Enteric valve; (E) Cushions of the enteric valve (arrow points to the spine). N, malpighian nodule; MT, malpighi tubules; $\mathrm{T}$, mesenteric tongue. This figure is in color in the electronic version. 
view, U-shaped above the mesenteron. Colon involves partially the paunch final portion, forming a curve to the right side that follows until it connects with the rectum through a slight muscular constriction. Rectum very broad, approximately of the same width of the gut (Figure $3 \mathrm{~B}$ ). Measurements of workers are presented in Table 1.

Imago: (Figures $5 \mathrm{~A}-\mathrm{D})$. Cephalic capsule brown, densely covered with several short bristles and few long bristles; fontanelle conspicuous, drop-shaped, forming a small depression on top of the head; ocelli small, semicircular and prominent. Eyes of medium size, rounded and protuberant. Postclypeus small, yellowish brown, almost trapezoidal and slightly inflated, with many bristles of different sizes distributed throughout its surface. Labrum with many bristles, with its widest part approximately with the same width of the postclypeus (Figure $5 \mathrm{~A}-\mathrm{B}$ ). In both antennae the last articles were broken: Antennomere I wider and approximately three times longer than II > III = IV to VII. The following antennomeres progressively increase in length. Pronotum light brown, covered with bristles, except in its middle part and just below the anterior lobe until near the margins; pronotum slightly narrower than the head; pronotal anterior part with microscopic hairs, median line weak, but visible in the anterior

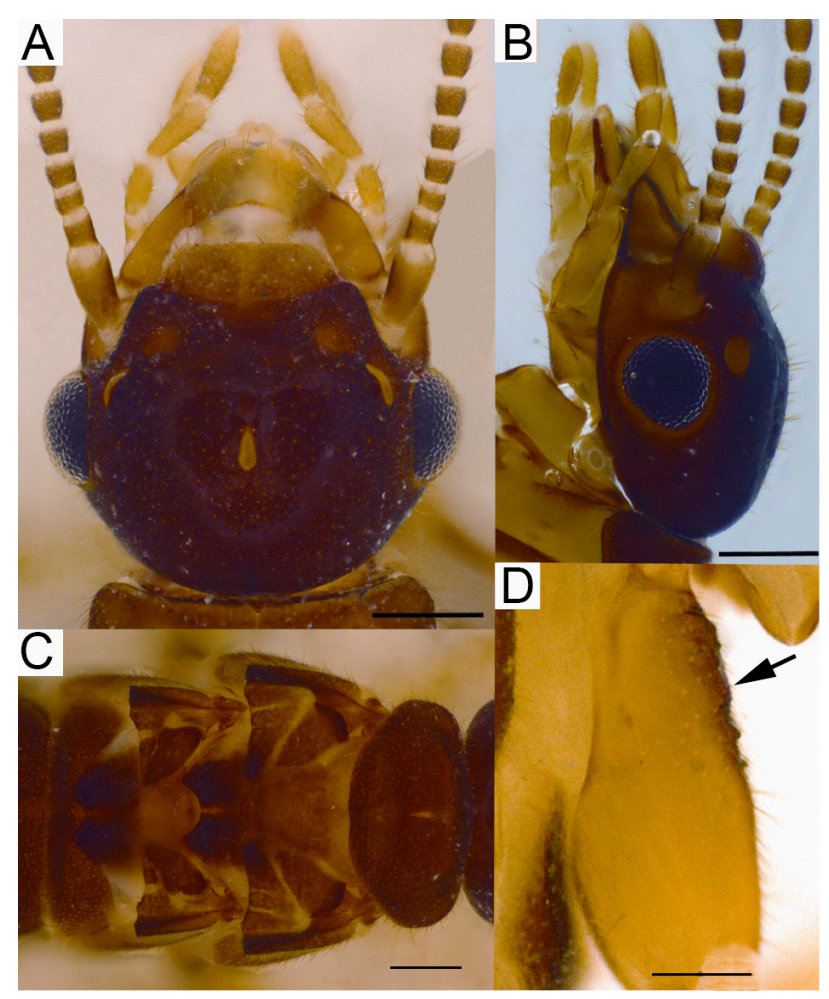

Figure 5. Imago of Dihoplotermes taurus sp. nov. (A) Head in dorsal view; (B) Head in lateral view; (C) Pro-, meso- and metanotum in dorsal view; (D) Procoxae in lateral view (arrow points to the anterior protuberances). This figure is in color in the electronic version. Scale bars: $A-C=0.3 \mathrm{~mm} ; \mathrm{D}=0.15 \mathrm{~mm}$. margin. Anterior portion of meso- and metanotum dark yellow and posterior portion dark brown. Anterior portions narrowing towards posterior portions, reaching the apex of the wing scales; anterior portions partially covered by the wing scales; posterior margins bilobate, mesonotal posterior margin semicircular shaped and metanotal posterior margin V-shaped. Bristles on dorsal surface (Figure $5 \mathrm{C}$ ). Tergites with the same color as the pronotum, with many small bristles and some long bristles. Sternites light brown on the lateral margins and dark yellow near the median line. A row of long bristles on the posterior margins of each sternite. The coxae first pair with small protuberances on the anterior proximal surface (Figure 5 D). Tibia long and thin. Only one imago was found and it was preserved. Therefore, mandibles were not extracted. Measurements of the imago are presented in Table 1.

Distribution and habitat. The colonies of Dihoplotermes taurus were found at the Experimental Farm of Universidade Federal do Amazonas (UFAM), located at km 38 of the BR174 highway, which connects the Brazilian cities of Manaus (Amazonas state) and Boa Vista (Roraima state) (Figure 6), a rainforest area that covers almost 3.000 ha. The climate is equatorial, warm and humid, with high rainfall during the rainy season (Kottek et al. 2006). The colonies were collected in the subsoil. Conspicuous nests were not found and the sampled individuals were collected in the soil during digging. We suppose that nests are located underground, diffuse in the soil.

\section{Comparison with similar taxa}

The soldiers of $D$. taurus sp. nov. differ from those of $D$. inusitatus by having a small projection in form of a spine with blunt apex on the postmentum, which is a unique characteristic of this species. However, workers of D. taurus share similarities in the gut with workers of $D$. inusitatus, such as the gizzard, malpighian tubules and enteric valve (Figures 4 and 7). Regarding phylogenetic and morphological differences between Palmitermes and Dihoplotermes (Hellemans et al. 2017), a smaller projection in the same region is also present in Palmitermes (Hellemans et al. 2017). However, both soldiers of Dihoplotermes have a lateral spine on each side of the head at the mandible base and a conspicuous frontal protuberance on the postmentum. In the non-dimorphic soldiers of D. taurus this protuberance is not projected forward as in the major soldiers of $D$. inusitatus. The frontal prominence observed in D. taurus sp. nov. is also present in Palmitermes and Termes. In our samples of $D$. taurus sp. nov. in multiple colonies, only one type of soldier was found, which might suggest that the soldier's caste of this species is monomorphic, whereas soldiers of $D$. inusitatus are dimorphic. The spine on the gizzard's puvillar belt is a unique characteristic of Neotropical termites. 


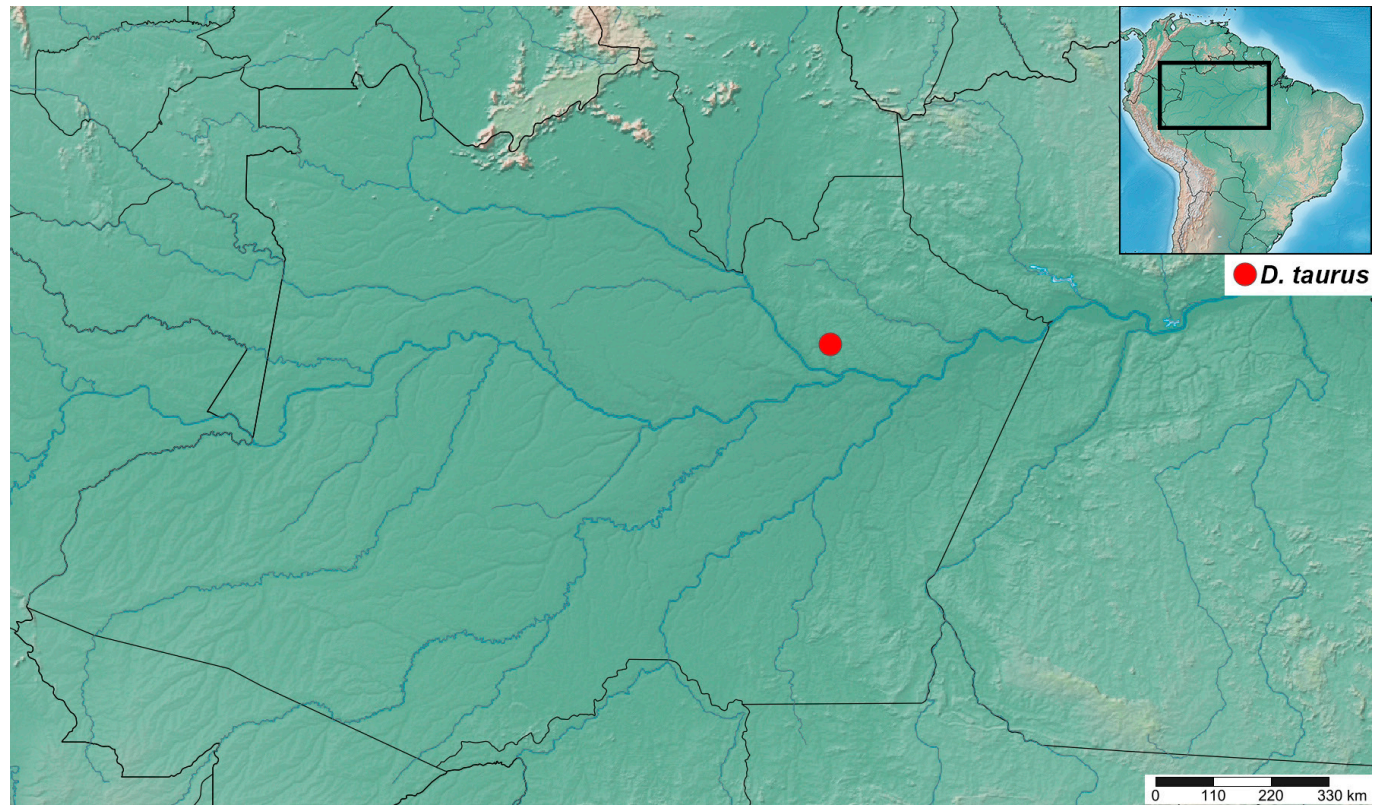

Figure 6. Location of the type locality of Dihoplotermes taurus sp. nov. in the central Brazilian Amazon.This figure is in color in the electronic version.

A

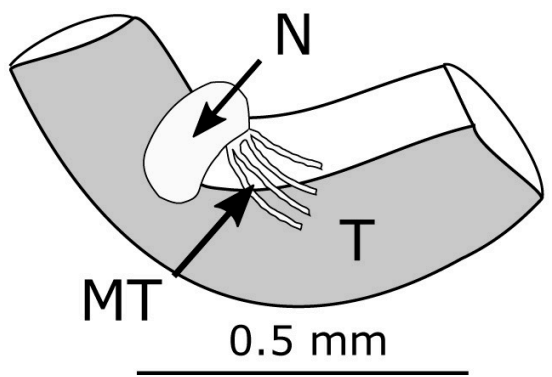

B
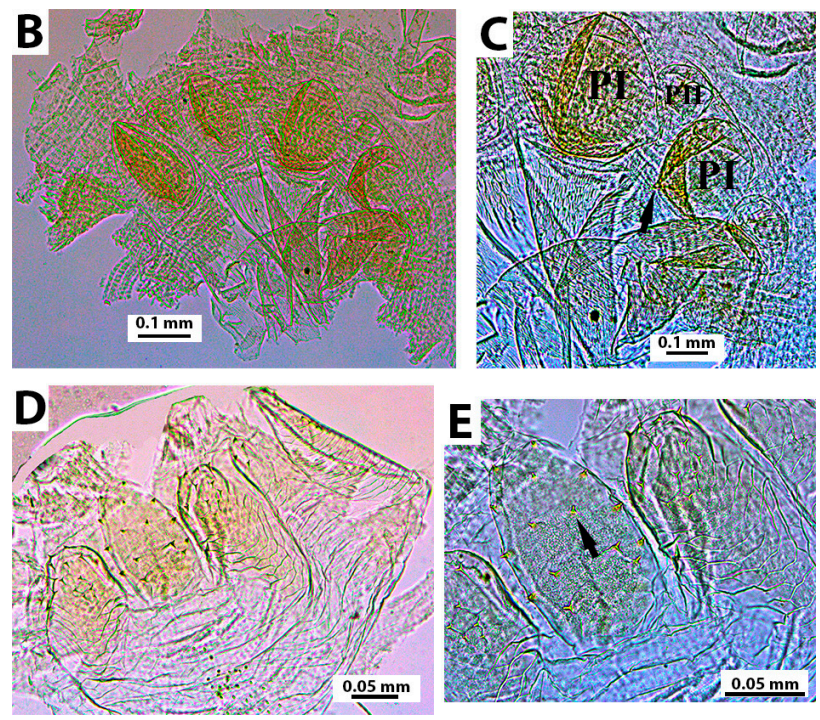

Figure 7. Digestive tube of the worker of Dihoplotermes inusitatus, sp. nov. (A) Insertion of malpighian tubules; (B) Gizzard; (C) PI, pulvilli I; PIl, pulvilli II (arrow points to a spine on the gizzard); (D) Enteric valve; (E) Cushions of the enteric valve (arrow points to the spine). N, malpighian nodule; MT, malpighian tubules; $\mathrm{T}$, mesenteric tongue. This figure is in color in the electronic version.

\section{DISCUSSION}

Recent phylogenies suggest that the Dihoplotermes and Spinitermes genera represent a sister clade to Cavitermes and Palmitermes, both in the Termes-group (Hellemans et al. 2017). All species of these four genera are Neotropical and form the Cavitermes lineage, supported mainly by mitochondrial genomes and chemical profiles of cuticular hydrocarbons. Although Divinotermes Carrijo \& Cancello was not included in this analysis, it shares noteworthy similarities with some genera of this lineage, i.e. the imago of Divinotermes with the imago of Cavitermes and soldiers of Divinotermes with soldiers of Spinitermes robustus (Snyder, 1926), as pointed out by Carrijo and Cancello (2011). Some genera of the Cavitermes lineage share traits of the mandibles of workers, as in Palmitermes and Cavitermes. Dihoplotermes is the most morphologically distinct genus in this group due to the traits of mandibles of workers and the asymmetry of the mandibles of soldiers. Asymmetrical mandibles evolved four times, which makes them plastic and more susceptible to environmental pressures and adaptive restrictions than to shared ancestry, which enhances the idea that only morphological traits may mask phylogenetic relationships (Inward et al. 2007). Although the gizzard has a thorn, which makes $D$. taurus distinct from other genera, the enteric valve is a remarkable character that notably places D. taurus near Palmitermes impostor Hellemans and Roisin, as both species have asymmetrical lobules, distinct from Cavitermes tuberosus (Emerson) and Termes fatalis Linnaeus (Hellemans et al. 2017). The morphological traits of D. taurus sp. nov., specially in the worker mandible, are highly similar to those of D. inusitatus, the type-species of the genus (personal 
observation, see also Araujo 1961). The internal structures of the digestive system, such as the gizzard and enteric valve, have been used for phylogenetic analyses (Hellemans et al. 2017). However, these structures were not described in $D$. inusitatus, the type-species of the genus.

As suggested by one anonymous reviewer, Araújo (1961) made one mistake describing the third marginal tooth in the left mandible of workers. As seen in Fontes (1987), whenever the third marginal is present, it is also visible in front of the molar tooth and never hidden beneath the molar prominence. Hence, we changed the diagnosis of Dihoplotermes replacing the third marginal by the molar tooth.

\section{CONCLUSIONS}

The description of $D$. taurus $\mathbf{n}$. sp. and the recent phylogenetic studies of the Termitinae (Bourguignon et al. 2017) and Termes-group (Hellemans et al. 2017) allowed us to compare these groups and to include the new species within the Termesgroup. Regarding the morphological similarities among the Dihoplotermes species, a review of all species in the genus and the Termes-group will be necessary to determine the phylogenetic positioning of the described species.

\section{ACKNOWLEDGMENTS}

We thank Pedro, Saba and Célio for support in field collections. We also thank Universidade Federal do Amazonas (UFAM) for allowing us to collect in the forest reserve of their experimental farm, and for providing us with accommodation, and Fundação de Amparo à Pesquisa do Estado do Amazonas (FAPEAM) for financial support (PRONEX project, edital 016/2006, proc. \# 1437/2007, coordinated by José Albertino Rafael). We also thank entomologist colleagues João Oliveira, Raphael Heleodoro and Rafael Sobral for suggestions on the manuscript, and Dr. Elizabeth Franklin for contributing and revising the English.

\section{REFERENCES}

Araújo, R.L. 1961. New genus and species of Brazilian termite (Isoptera, Termitidae, Termitinae). Revista Brasileira de Biologia, 21: 105-111.

Bourguignon, T.; Lo, N.; Cameron, S.L.; Šobotník, J.; Hayashi, Y.; Shigenobu, S.; Watanabe, D.; Roisin, Y.; Miura, T.; Evans, T.A. 2015. The evolutionary history of termites as inferred from 66 mitochondrial genomes. Molecular Biology and Evolution, 32: 406-421.

Bourguignon, T.; Lo, N.; Šobotník, J.; Ho, S.Y.W.; Iqbal, N.; Coissac, E.; et al. 2017. Mitochondrial phylogenomics resolves the global spread of higher termites, ecosystem engineers of the tropics. Molecular Biology and Evolution, 34: 589-597.
Carrijo, T.F.; Cancello, E.M. 2011. Divinotermes (Isoptera, Termitidae,Termitinae), a New Genus from South America. Sociobiology, 58: 537-556.

Constantino, R. 2002. An illustrated key to Neotropical termite genera (Insecta: Isoptera) based primarily on soldiers. Zootaxa, 67: $1-40$.

Constantino, R. 2018. Catálogo on-line (http://164.41.140.9/ catal/). Accessed on 29/01/2018.

Fontes, L.R. 1987. Morphology of the alate and worker mandibles of the soil-feeding nasute termites (Isoptera, Termitidae, Nasutitermitinae) from the Neotropical Region. Revista Brasileira de Zoologia, 3: 503-531.

Hellemans, S; Bourguignon, T; Kyjaková, P; Hanus, R; Roisin, Y. 2017. Mitochondrial and chemical profiles reveal a new genus and species of Neotropical termite with snapping soldiers, Palmitermes impostor (Termitidae: Termitinae). Invertebrate Systematics, 31: 394-405.

Inward, D.J.G.; Vogler, A.P.; Eggleton, P. 2007. A comprehensive phylogenetic analysis of termites (Isoptera) illuminates key aspects of their evolutionary biology. Molecular Phylogenetics and Evolution, 44: 953-967.

Kottek, M.; Grieser, J.; Beck, C.; Rudolf, B.; Rubel, F. 2006. World Map of the Köppen-Geiger climate classification updated. Meteorologische Zeitschrift, 15: 259-263.

Krishna, K. 1968. Phylogeny and generic reclassification of the Capritermes complex (Isoptera, Termitidae, Termitinae). Bulletin of the American Museum of Natural History, 138: 261-324.

Krishna, K.; Araujo, R.L. 1968. A revision of the Neotropical termites genus Neocapritermes (Isopera, Termitidae, Termitinae). Bulletin of the American Museum of Natural History, 138: 85-130.

Mathews, A.G.A. 1977. Studies on termites from the Mato Grosso state, Brazil. Academia Brasileira de Ciências, Rio de Janeiro, 267p.

Noirot, C. 1995. The gut of termites (Isoptera). Comparative anatomy, Systematics, Phylogeny. I. Lower termites. Annales de la Société Entomologique de France, 31: 197-226.

Noirot, C. 2001. The gut of termites (Isoptera). Comparative anatomy, systematic, phylogeny. II. Higher termites (Termitidae). Annales de la Société Entomologique de France, 37: 431-471.

Roonwal, M.L. 1970. Measurement of termites (Isoptera) for taxonomic purposes. Journal of the Zoological Society of India, 21: 9-66.

Shorthouse, D.P. 2010. SimpleMappr, an online tool to create free point maps for publications and presentations. Available from (http://simplemappr.net). Accessed on 01/02/2018.

RECEIVED: 01/03/2018

ACCEPTED: 13/09/2018

ASSOCIATE EDITOR: Claudia Keller 